http://dx.doi.org/10.12775/szhf.2017.011

\author{
WOJCIECH SAK
}

Uniwersytet MikoŁaja Kopernika, Toruń, Polska

WOJCIECH.R.SAK@GMAIL.COM

\title{
Problem autonomii w ujęciu kognitywistycznym
}

\section{Wstęp}

Kognitywistyka, realizując program badawczy polegający na odkrywaniu i dążeniu do zrozumienia mechanizmów poznania ${ }^{1}$ oraz zmierzając do uzyskania syntezy wiedzy na temat umysłu², coraz częściej dotyka obszarów omawianych dotąd przede wszystkim w filozofii, która tym samym stała się dla niej źródłem inspiracji oraz wyzwań, zawierając wiele szczegółowo rozpatrzonych problemów dotyczących między innymi pojęć mających znaczenie dla opisu ludzkich działań. Jednym z nich jest pojęcie autonomii, z którym wiąże się szereg pytań: jak właściwie należy określić czym jest? czy można ją w jakiś sposób skategoryzować, a jeżeli tak, to jak i na podstawie czego? czy można ją ująć ilościowo ponad prostą relację jej obecności bądź braku? Jeżeli uda się znaleźć odpowiedzi na te pytania, pozwoli to sformułować odpowied-

${ }^{1}$ U. M. Żegleń, Epistemologia a kognitywistyka, [w:] Przewodnik po epistemologii, red. R. Ziemińska, WAM, Kraków 2013, s. 457.

${ }^{2}$ W. Duch, wykład „Wstęp do kognitywistyki”, Uniwersytet Mikołaja Kopernika, https:// www.fizyka.umk.pl/ duch/Wyklady/Kog1/01-wstep.htm (dostęp: 12.05.2016). 
nie cele badawcze, które po fazie eksperymentalnej mogą naprowadzić na odpowiedzi dotyczące takich zagadnień, jak na przykład aspekt rozwojowy autonomii - autonomizacja w przebiegu życia, aktywne kształtowanie własnej tożsamości czy aspekt poznawczy - poznawania samego siebie.

Przygotowanie do rozpatrzenia znaczenia pojęcia autonomii w kognitywistyce można zacząć od przedstawienia podziału zagadnienia na dwa problemy: autonomii podmiotowej oraz bezpodmiotowej.

\section{Problem autonomii podmiotowej}

Dotyczy tego czy i w jaki sposób jednostka może kierować swoim losem. Wiąże się to między innymi z odnajdywaniem się w nowych dla siebie sytuacjach, zatem powstaje pytanie: jak osoba definiuje się względem środowiska, czy jest to zjawisko automatyczne, czy jednak należy wskazać na konieczną aktywną rolę podmiotu? Jakie mechanizmy stoją za jej samosterownością, a jakie za jej samoregulacją? W jakim stopniu i w jakich obszarach jest do tego zdolna? Na ile może poznać samą siebie i dlaczego jest to takie ważne dla jej autonomii? Jaki jest profil jej swobody działania w różnych warunkach? Na czym miałyby polegać warunki optymalne działania, a w związku z tym, czym są optymalne decyzje? Jakie są warunki konieczne i wystarczające dla obecności autonomii? Czy zawsze da się określić występowanie autonomii u osoby? Jakie są jej rodzaje? Czym jest autonomia pozorna? Czy dla uzyskania autonomii należy czasem $\mathrm{z}$ niej zrezygnować? Jakie są związki autonomii ze zdrowiem psychicznym?

\section{Problem autonomii bezpodmiotowej}

Dotyczy zagadnienia istnienia autonomii $\mathrm{w}$ systemach podejmujących działania, lecz pozbawionych jaźni, czyli w automatach bądź pewnych klasach systemów, których aktywność jest pozbawiona zewnętrznego kontrolera. Podstawowe staje się pytanie, czy w ogóle można mówić o autonomii bezpodmiotowej, a jeżeli tak, to na jakich warunkach? Czy automaty mogą być autonomiczne? Czy abstrakcyjne rozważania na temat autonomii (niezależności różnych systemów, maszyn, automatów), które mogą wiązać się $\mathrm{z}$ redukcją terminów stosowanych do opisu autonomii podmiotowej, będą mogły pomóc w powiedzeniu czegoś interesującego na temat natury autonomii osoby? Czy szczegółowa formalizacja autonomii jest możliwa? 
Powyższa lista nie wyczerpuje wszystkich pytań związanych $\mathrm{z}$ autonomią w ujęciu kognitywistycznym, natomiast zarysowuje ona złożoność pojawiających się problemów.

Niniejsze rozważania skupiają się na problemie autonomii podmiotowej z powodu jej dużego znaczenia dla opisu psychiki człowieka. Stanowi bardzo ważną wartość, ze względu na związaną z nią jakość przeżywania swojego życia. W słowniku psychologii można przeczytać bardzo krótką i ogólną definicję stanu, jakim jest autonomia opisującą ją po prostu jako "niezależność”, mając na myśli samodzielność, przez zaznaczenie osobności i odrębności jednostki. Dalej jednak znajdziemy bardziej dynamiczny opis w odniesieniu do osoby, określenie jej jako autonomicznej będzie oznaczało jej zdolności do samokontroli lub samoregulacji czy wewnątrzsterowności, a nawet do spontaniczności ${ }^{4}$. Autonomiczne działanie w kontraście do kontrolowanej regulacji ma $\mathrm{w}$ teoriach psychologicznych znaczenie dla jakości wykonania osiąganych celów, wytrwałości, jakości relacji międzyludzkich i doświadczeń emocjonalnych, ogólnego dobrostanu, zdrowego rozwoju, kreatywności i społecznej integracji ${ }^{5}$.

Przyjrzyjmy się, jak ujmowana jest autonomia podmiotowa w dwóch rozbudowanych kontekstach, które pozwolą zapoznać się z dotychczasowymi teoriami na ten temat, czyli w kontekście filozoficznym $\mathrm{z}$ teoriami autonomii personalnej oraz $\mathrm{w}$ psychologicznym $\mathrm{z}$ teorią autonomii jako autodeterminacji.

\section{Kontekst filozoficzny - autonomia personalna}

Teorie autonomii personalnej podejmują próby uzasadnienia, jakie kryteria powinny być brane pod uwagę $\mathrm{w}$ różnych przypadkach, aby móc ustalić i uzasadnić, czy jednostka rzeczywiście kierowała poprzez swoje decyzje swoim losem, odwołując się przy tym niejednokrotnie do własności życia psychicznego osób. Autonomię personalną należy rozumieć jako zdolność,

${ }^{3}$ A. S. Reber, Słownik psychologii, red. I. Kurcz i K. Skarżyńska, Wydawnictwo Naukowe SCHOLAR, Warszawa 2002, s. 68.

${ }^{4}$ Tamże.

${ }^{5}$ R. M. Ryan, E. L. Deci, Self-Regulation and the Problem of Human Autonomy: Does Psychology Need Choice, Self-Determination, and Will?, „Journal of Personality”, grudzień 2006, nr 74.6, s. 1557-1586. 
czy wręcz możność niezależnego decydowania o samym sobie, realizację własnych dążeń, posiadanie kierunku działania w swoim życiư ${ }^{6}$. Często nie bierze się tu pod uwagę żadnych odniesień do moralności ${ }^{7}$.

Cztery podejścia teoretyczne przedstawiają różne odpowiedzi na pytanie „co odróżnia podważające autonomię wpływy na decyzje, intencje lub wolę osoby od tych kierujących oddziaływań, które zaledwie odgrywają pewną rolę $w$ procesie samostanowienia?" nie jest możliwe ze względu na trudno uchwytną, często delikatną naturę przyczynowości zjawisk (jak choćby w niestabilnej neurodynamice mózgu' ${ }^{9}$ ), niemniej taka próba może okazać się skuteczna poprzez wskazanie na warunki idealne autonomii i braku autonomii. Na przykład istnieje konsensus w takich przypadkach, jak pranie mózgu czy uzależnienie jako prototypowych przypadków podważających autonomię, ale brak go przy ustalaniu precyzyjnej natury tych zagrożeń, które będzie skutkowało odpowiednimi osądami moralnymi i decyzjami prawnymi, choć różne definicje mają wiele punktów wspólnych. Oto najważniejsze teorie autonomii personalnej:

1. Podejścia koherentystyczne - podstawą uznania sprawcy za autonomicznego jest istnienie pewnej spójności pomiędzy jego działaniem a tym, co należy uznać za jego własne przekonania. Precyzowanie owej spójności wygląda następująco: „sprawca kieruje swoimi działaniami wtedy i tylko wtedy, gdy jest zmotywowany, aby działać w dany sposób, ponieważ owe motywacje są spójne (są w harmonii) z pewnymi stanami mentalnymi reprezentującymi jego punkt widzenia" ${ }^{\prime 10}$. Spory istnieją w kwestii tego, co należy uznać za takie stany, mogą to być:

a. tak zwane pragnienia najwyższego $\mathrm{rzędu}^{11}$

\footnotetext{
${ }^{6}$ J. Dryden, Internet Encyclopedia of Philosophy. A Peer-Reviewed Academic Resource http:// www.iep.utm.edu/autonomy/ (dostęp: 12.05.2016).

7 Tamże.

${ }^{8}$ S. Buss, Personal Autonomy, [w:] The Stanford Encyclopedia of Philosophy (Winter 2014 Edition), E. N. Zalta (ed.), http://plato.stanford.edu/archives/win2014/entries/personal-autonomy/.

${ }^{9}$ W. Duch, Czy jesteśmy automatami? Mózgi, wolna wola i odpowiedzialność, [w:] Na ścieżkach neuronauki, red. P. Francuz, Wydawnictwo KUL, Lublin 2010, s. 219-264.

${ }^{10} \mathrm{~S}$. Buss, Sarah, dz. cyt.

${ }^{11}$ S. Buss, za: H. G. Frankfurt, Freedom of the Will and the Concept of a Person, [w:] The Importance of What We Care About: Philosophical Essays, Cambridge University Press, Cambridge 1988, s. 11-25.
} 
b. sądy wartościujące, które działania są najkorzystniejsze ${ }^{12}$

c. stany wynikające z planów długoterminowych ${ }^{13}$

d. warunki we względnie stabilnej sieci stanów emocjonalnych związanych z dbałością, ostrożnością ${ }^{14}$

e. cechy charakteru sprawcy ${ }^{15}$

f. najgruntowniej zintegrowane stany psychiczne ${ }^{16}$.

2. Koncepcja responsywności na racje (reasons-responsive) - „sprawca nie kieruje sobą, chyba że jego motywy lub procesy mentalne je produkujące są responsywne na wystarczająco szeroki zakres powodów za i przeciw zachowywaniu się w taki sposób, jaki on wybiera"17.

W podejściach tego typu sprawca, który jest nieresponsywny na argumentację „stojącą za" lub „wspierającą" takie, a nie inne motywy, nie jest we właściwej pozycji do autoryzacji swoich zachowań [jako własnych - przyp. W. S.]. Bez względu na to, czy trafne rozumowanie ma swoje ugruntowanie $\mathrm{w}$ faktach o pragnieniach i interesach sprawcy lub czy mają swoje niezależne źródło, pogląd jest taki, że nie można kogoś zakwalifikować jako samosterującego, jeśli nie potrafi zrozumieć, ku czemu ma (naprawdę) powody, aby czynić lub (jeśli występuje wyraźna ułomność) jest niezdolny do bycia poruszonym przez takie rozumowanie. [...] jest mało prawdopodobne, że osoba

12 S. Buss, za: G. Watson, Free Agency, „Journal of Philosophy”, 1975, nr 72, s. 205-220.

${ }^{13}$ S. Buss, za: M. Bratman, Practical Reasoning and Weakness of the Will, „Noûs”, 1979, nr 13, s. 131-151; M. Bratman, Structures of Agency: Essays, Oxford University Press, Oxford 2007.

${ }^{14}$ S. Buss, za: H. Frankfurt, Freedom of the Will and the Concept of a Person, 1988, s. 11-25;

H. Frankfurt, Necessity, Volition and Love, Cambridge University Press, Cambridge 1999, s. 155-180; D. Shoemaker, Caring, Identification, and Agency, „Ethics”, 2003, nr 114(1), s. $88-118$.

${ }^{15}$ S. Buss, za: R. Dworkin, Life's Dominion, Random House, Inc., New York 1994.

${ }^{16}$ S. Buss, za: N. Arpaly, T. Schroeder, Praise, Blame, and the Whole Self, „Philosophical Studies", 1999, nr 93, s. 161-88.

${ }^{17}$ S. Buss, za: D. Nelkin, Do We Have a Coherent Set of Intuitions about Moral Responsibility?, „Midwest Studies in Philosophy”, 2007, nr 31, s. 243-59; S. Wolf, Asymmetrical Freedom, "Journal of Philosophy“, 1980, nr 77, s. 151-166 (przedrukowano w: J. Fischer, Moral Responsibility, Cornell University Press, Ithaca 1986, s. 225-40); S. Wolf, The Importance of Free Will, „Mind”, 1986, nr 90, s. 386-405 (przedrukowano w: J. Fischer i M. Ravizza, Perspectives on Moral Responsibility, Cornell University Press, Ithaca 1993, s. 101-118), S. Wolf, Sanity and the Metaphysics of Responsibility, [w:] Responsibility, Character and the Emotions: New Essays in Moral Philosophy, (red.) F. Schoeman, Cambridge University Press, Cambridge 1987, s. 46-62; S. Wolf, Freedom within Reason, Oxford University Press, New York 1990. 
której nie udaje się docenić szerokiego zakresu powodów do działania, będzie w stanie kierować sobą dobrze [dokładnie, w dużym stopniu - przyp. W. S.]: jest prawdopodobne, że taka osoba w swoim długoterminowym postępowaniu udaremni swoje własne zamiary, cele i korzyści. Koncepcja autonomii jako responsywności na racje zdaje się zatem odzwierciedlać intuicję, że jeżeli robimy coś bardzo kiepsko, to nie robimy tego wcale ${ }^{18}$.

Można obrazowo powiedzieć, że responsywność na racje polega na dopasowywaniu motywów do racji, a dopiero później po dokonanej takiej regulacji następuje działanie.

3. Koncepcja responsywności na wyciąganie wniosków (responsiveness-to-reasoning) - jest to podejście wspierające koncepcję responsywności na racje, ale nacisk jest tutaj położony na proces wnioskowania sam w sobie. Jak napisała o tym dalej Sharah Buss w artykule o autonomii personalnej:

stoi za tym myśl, że jeżeli ktoś nie potrafi zareagować na racje, to oznacza, że musi mieć ograniczoną zdolność do wnioskowania. [...] esencją samosterowności jest zdolność do oceny swoich motywów na bazie tego, jakie są moje przekonania i pragnienia oraz dostosowanie owych motywów do swoich oszacowań. $[\ldots]^{19}$.

Za tą koncepcją stoi przekonanie, że "autonomiczne sprawstwo jest możnością zdystansowania się od swoich własnych nastawień i przekonań" ${ }^{20}$ (tak samo jest w koherentystycznym podejściu) oraz że „samosterowanie wymaga zdolności do transformowania siebie"21, a więc do plastyczności zachowań. Przykładem takiej responsywności mogłoby być zdanie sobie sprawy przez podmiot $z$ tego, że jego pragnienia i cele (najwyższego rzędu) stoją w sprzeczności z dotychczasowymi przekonaniami nabytymi drogą indoktrynacji. Osoba, która nie jest w stanie zmienić takich przekonań, choć z jej pragnień wynikałaby taka konieczność, nie może zostać uznaną za autonomiczną, jest „sterowana przez swoich programatorów, nie przez samą siebie”22.

4. Podejście inkompatybilistyczne - odpowiada ono założeniu, że nie można uznać za autonomiczne takich działań i motywów,

\footnotetext{
${ }^{18}$ S. Buss, dz. cyt.

19 Tamże.

${ }^{20}$ Tamże.

${ }^{21}$ Tamże.

${ }^{22}$ Tamże.
} 
które są „przyczynowo zdeterminowane zdarzeniami, nad którymi nie mamy żadnej kontroli”23.

\section{Kontekst psychologiczny - autonomia jako autodeterminacja}

Zgodnie z empirycznie potwierdzoną teorią autodeterminacjii ${ }^{24}$ (SDT self-determination theory) opracowaną przez Richarda Ryana i Edwarda Deciego, autonomia „stanowi obok kompetencji i przynależności, jedną z trzech podstawowych, wrodzonych i uniwersalnych ludzkich potrzeb, których spełnienie pozwala na osiągnięcie dobrostanu” 25 i wspiera „najbardziej wolicjonalne i najwyższej jakości formy motywacji i zaangażowania w podejmowane aktywności, włączając w to polepszone wykonanie, wytrwałość i kreatywność” ${ }^{26}$. Sama potrzeba autonomii „dotyczy ludzkiego pragnienia bycia przyczynowym sprawcą, doświadczania wolicjonalności, działania w zgodzie ze zintegrowanym poczuciem samego siebie (np. ze swoimi zainteresowaniami i wartościami) oraz zaaprobowania swojego działania na najwyższym poziomie zdolności do refleksji”27. Jednym z celów definiowania autonomii w kontekście psychologicznym jest jej funkcjonalna identyfikacja przy określeniu, czy osoba działa motywowana wewnętrznie (autonomicznie), czy zewnętrznie (w warunkach kontroli). Przyjmuje to postać ewaluacji psychologicznej mającej znaczenie dla przeprowadzania badań naukowych lub w przebiegu psychoterapii. Dokładne różnice pomiędzy oboma rodzajami motywacji oraz związanym z nimi zjawiskiem autonomii przedstawia poniższa tabela ${ }^{28}$ :

${ }^{23}$ Tamże, za: D. Pereboom, Determinism el Dente, „Nous”, 1995, nr 29, s. 21-45; D. Pereboom Living Without Free Will, Cambridge University Press, Cambridge 2001.

${ }^{24}$ R. M. Ryan, E. L. Deci, dz. cyt.

${ }^{25}$ E. L. Deci, M. Vansteenkiste, Self-determination theory and basic need satisfaction: Understanding human development in positive psychology, "Ricerche di Psichologia”, 2004, nr 27, s. 17-34.

${ }^{26}$ Oficjalna witryna internetowa poświęcona Teorii Autodeterminacji, lista osób redagujących http://selfdeterminationtheory.org/faculty/, http://selfdeterminationtheory.org/theory/ (dostęp: 28.03.2016).

${ }^{27}$ E. L. Deci, M. Vansteenkiste, dz. cyt.

${ }_{28}$ Tabela - opracowanie własne na podstawie R. M. Ryan E. L. Deci, Autonomy is no Illusion, [w:] Handbook of Experimental Existential Psychology, red. J. Greenberg, S. L. Koole, T. Pyszczynski, The Guilford Press, New York-London 2004, s. 449-479; R. M. Ryan, E. L. Deci, Self-Regulation and the Problem of Human Autonomy: Does Psychology Need Choice, 


\begin{tabular}{|c|c|}
\hline Rodzaj motywacji & Charakterystyka \\
\hline $\begin{array}{l}\text { WEWNĘTRZNA } \\
\text { (intrinsicmotivation) }\end{array}$ & $\begin{array}{l}\text { Tendencja do podejmowania i wytrwałego kontynuowania } \\
\text { działania wyłącznie ze względu na zainteresowanie nim } \\
\text { i satysfakcję, jakiej ono dostarcza. Tendencja ta według } \\
\text { autorów teorii autodeterminacji stanowi wyraz nat u- } \\
\text { raln e go i wrodzon e go u ludzi dąż en ia do } \\
\text { poszukiwania wyzwań i nowości. Ściśle wiąże się ona z roz- } \\
\text { wojem poznawczym i społecznym. Według Ryana i Deciego } \\
\text { ten typ motywacji stanowi prototyp motywacji autono- } \\
\text { micznej. }\end{array}$ \\
\hline $\begin{array}{l}\text { MOTYWACJA ZEWNĘTRZNA } \\
\text { (extrinsicmotivation) }\end{array}$ & $\begin{array}{l}\text { Tendencja do podejmowania i wytrwałego kontynuowania } \\
\text { działania ze względu na pewne zewnętrzne rezultaty, do ja- } \\
\text { kich ma ono doprowadzić. Źr ódłe m tego typu mo- } \\
\text { ty wacji jest kontekst społe czny, który w zależ- } \\
\text { ności od tego, w jakiej mierze zaspokaja trzy podstawowe } \\
\text { potrzeby (przynależności, kompetencji i autonomii), pro- } \\
\text { wadzi do ukształtowania motywacji zewnętrznej o różnym } \\
\text { stopniu autonomii (stanowiącej kontinuum internalizacji } \\
\text { (internalization) - od regulacji zewnętrznej do regulacji } \\
\text { zintegrowanej): }\end{array}$ \\
\hline $\begin{array}{l}\text { Zachowanie zewnętrznie regulowane } \\
\text { (externallyregulatedbehavior) }\end{array}$ & $\begin{array}{l}\text { Najmniej autonomiczny typ motywacji, ponieważ działanie } \\
\text { podejmowane jest wyłącznie ze względu na zewnętrzne wy- } \\
\text { magania bądź wzmocnienia; }\end{array}$ \\
\hline $\begin{array}{l}\text { Zachowanie regulowane na podstawie } \\
\text { introjekcji (introjectedregulation } \\
\text { of behaviour) }\end{array}$ & $\begin{array}{l}\text { Nieautonomiczny typ motywacji, oznacza działanie pod } \\
\text { wpływem standardu, który nie został zaakceptowany i włą- } \\
\text { czony w zakres Ja. Przymus zewnętrzny, który towarzyszy } \\
\text { działaniu o charakterze zewnętrznej regulacji, zostaje w tym } \\
\text { przypadku zastąpiony przez przymus wewnętrzny i jednost- } \\
\text { ka podejmuje działanie zgodnie z wymaganiami po to, aby } \\
\text { uniknąć takich negatywnych uczuć, jak poczucie winy bądź } \\
\text { wstyd, czy też aby potwierdzić własną wartość; }\end{array}$ \\
\hline $\begin{array}{l}\text { Regulacja na podstawie identyfikacji } \\
\text { (regualtionthroughidentification) }\end{array}$ & $\begin{array}{l}\text { Reprezentuje autonomiczny typ motywacji zewnętrznej, } \\
\text { w której ramach jednostka rozumie sens i znaczenie danego } \\
\text { standardu, pozytywnie go wartościuje i akceptuje; }\end{array}$ \\
\hline $\begin{array}{l}\text { Zintegrowana regulacja } \\
\text { (integratedregulation) }\end{array}$ & $\begin{array}{l}\text { Najbardziej autonomiczny charakter motywacji zewnętrz- } \\
\text { nej. Taki charakter regulacji jest rezultatem pełnego zinte- } \\
\text { growania standardu z systemem osobistych wartości, po- } \\
\text { trzeb i dążeń. }\end{array}$ \\
\hline
\end{tabular}

Self-Determination, and Will?, „Journal of Personality”, 2006, nr 74.6, s. 1557-1586 (na podstawie tłumaczenia: R. Kadzikowska-Wrzosek, Siła woli: autonomia, samoregulacja i kontrola działania, Wydawnictwo Smak Słowa, Sopot 2013, tabela nr 4, s. 82-83). 
Motywacja wewnętrzna a motywacja zewnętrzna w teorii autodeterminacji (Self-Determination Theory - STD) Ryana i Deciego.

\section{Podsumowanie kontekstu filozoficznego i psychologicznego autonomii}

Kontekst filozoficzny i psychologiczny łączy potrzeba wskazania ideału autonomii tak, aby stanowił on punkt odniesienia dla rozważań praktycznych i ułatwienie ustalania warunków minimalnych autonomii. Niestety nawet najdokładniejsze abstrahowanie jest wystawione na trudne wyzwania w zetknięciu z rzeczywistością z powodu wikłania się w ustalenia, co jest właściwie punktem widzenia sprawcy, czy istnieje takie jego nastawienie, od którego nie mógłby się on wyalienować ${ }^{29}$. Na przykład jak stwierdza Sarah Buss, okazuje się, że koherencja wcale nie musi być konieczna, aby działanie mogło zostać uznane za autonomiczne ${ }^{30}$. Mogą zaistnieć warunki, w których osoba pomimo swoich długoterminowych planów, musi podjąć decyzję niezgodną $\mathrm{z}$ nimi, ale mimo to uznamy ją za autonomiczną, choćby tylko dlatego, że autoryzuje ona zmianę decyzji ${ }^{31}$. Utrudnia to jednak znalezienie minimalnych warunków dla istnienia autonomii (bogatszych od samej tylko zdolności do autoryzacji działania), ponieważ wydaje się, że nie ma jednej niezmiennej kategorii stanów mentalnych, na podstawie której należałoby wnioskować $\mathrm{o}$ autonomii $\mathrm{w}$ danym przypadku ${ }^{32}$. Niemniej, integrując oba konteksty, można powiedzieć, że autonomia podmiotowa zawsze odnosi się do niezależności osoby, która jest w stanie podejmować samodzielne i dobrowolne decyzje, a w idealnych warunkach wynikają one z motywacji wewnętrznej. Analiza autonomii podmiotowej zarówno w kontekście filozoficznym, jak i psychologicznym jest rozważaniem o wymiarze kognitywistycznym. Aby odpowiedzieć na wcześniej wspomniane pytanie „co odróżnia podważające autonomię wpływy na decyzje, intencje lub wolę osoby od tych kierujących oddziaływań, które zaledwie odgrywają pewną rolę w procesie samostanowienia?", należy przyjąć na nie wiele perspektyw, w tym filozoficzną oraz psychologiczną, które wyznaczają kierunek badań mających odkryć, czy jednostka jest w stanie kierować swoim losem oraz jakie stoją za tym mechanizmy.

\footnotetext{
29 S. Buss, dz. cyt.

30 Tamże.

31 Tamże.

32 Tamże.
} 
Konsekwencje dociekań kognitywistycznych na temat autonomii prowadzą do zagadnienia problemu wolnej woli. Ma to miejsce nie tylko z poziomu jej kompatybilizmu $\mathrm{z}$ determinizmem, ale także pokazywania aktywnej roli podmiotu w zdeterminowanym świecie.

\section{Autonomia a wolna wola}

W ujęciu kognitywistycznym problem autonomii podmiotowej przyjmuje formę poszukiwania zrozumienia wolnej woli - tego, czy naprawdę istnieje ${ }^{33}$, a jeśli tak, to jakie jest jej znaczenie dla aktywności osoby ${ }^{34}$. Poniżej wykażę, że autonomię można utożsamić $\mathrm{z}$ wolną wolą.

Wskazówkę dla możliwości wyznaczenia relacji równoważności pomiędzy autonomią podmiotową i wolną wolą można dostrzec w uwagach Immanuela Kanta na temat rozumu praktycznego, którego zdolność „pozwalająca na wybór swoich własnych działań zakłada, że rozumiemy samych siebie jako wolnych w działaniu, niezależnych od ograniczeń zewnętrznych względem naszej woli” ${ }^{35}$. Podobnie już pierwsze dwa zdania pracy Józefa Bremera o wolnej woli zwracające uwagę na to, że jest ona jednym z atrybutów osoby, pozwalającym na podejmowanie samodzielnych i dobrowolnych decyzji36. Jak można zauważyć, zarówno Kant, jak i Bremer wskazują na najważniejsze cechy obecne w autonomii podmiotowej, czyli właśnie odniesienie do osoby, niezależność, którą uznaję za podstawę autonomii jako takiej oraz dobrowolność decyzji (wyrażoną choćby w tym, że mogę zaautoryzować dowolną wybraną przez siebie decyzję jako własną, co będzie działaniem autonomicznym). Bremer w przeglądzie kryteriów filozoficznych wolnej woli wskazuje także na racjonalność podmiotu (refleksja przed działaniem), zasadę autonomii jako wolności od przymusu wewnętrznego i zewnętrznego pozwalającą na działanie $w$ zgodzie $z$ samym soba ${ }^{37}$. Uznaję powyższe cechy wolnej woli za

${ }^{33}$ K. Smith, Neuroscience vs philosophy: Taking aim at free will, „Nature”, 2011, nr 477, s. 23-25 .

${ }^{34}$ K. D. Vohs, J. W. Schooler, The Value of Believing in Free Will, „Psychological Science”, 2008, nr 19(1), s. 49-54.

${ }^{35}$ J. Dryden, Internet Encyclopedia of Philosophy. A peer-review academic resource, http:// www.iep.utm.edu/autonomy/ (dostęp: 10.03.2016).

${ }^{36}$ J. Bremer, dz. cyt., s. 9.

37 Tamże, s. 33-35. 
wystarczające dla utożsamienia jej z autonomią podmiotową, co z kolei skłania do przyjrzenia się studiom nad wolną wolą w psychologii.

Ogólnie rozważań nad zjawiskiem wolnej woli w psychologii eksperymentalnej dokonuje się przy użyciu pojęćs ${ }^{38}$.

1) Samoregulacji (rozumianej nie tylko jako działanie w warunkach motywacji wewnętrznej zgodnie $\mathrm{z}$ teorią autodeterminacji, ale także jako zdolność do emocjonalnego opanowania się, uspokojenia czy pocieszenia samego siebie, modulowania i hamowania swojego nastroju oraz „elastycznej kontroli zachowania w różnych sytuacjach w ramach danej kultury" ${ }^{39}$ ).

2) Kontroli działania.

3) Plastyczności behawioralnej.

4) Świadomego podejmowania decyzji.

Jak stwierdza Roy F. Baumeister, psycholog znany z badań nad siłą woli, podejście psychologii do badania wolnej woli polega między innymi na ustaleniu, co ludzie mają na myśli, posługując się koncepcjami wolności, wyboru i odpowiedzialności (z czego między innymi wynikają powyższe pojęcia ogólne $)^{40}$. Owe fenomeny życia codziennego są później przekładane na eksperymentalnie weryfikowalne wewnętrzne czynniki je tworzące, co pozwala dokładniej odpowiedzieć na pytanie, „co czyni działanie wolnym?”"11. Za wolne, jak wynika $\mathrm{z}$ badań ${ }^{42}$, ludzie najczęściej uznają następujące działania:

1) podjęte po świadomej refleksji;

2) wbrew zewnętrznym naciskom;

3) wbrew swojemu krótkoterminowemu interesowi;

4) podejmowane w dążeniu do realizacji celów długoterminowych.

Można zauważyć spójność tych potocznych spostrzeżeń z kryteriami autonomii personalnej. Jednak pierwsza różnica pojawia się przy tym, że naukowa psychologia dąży do analizy źródła funkcjonalnie rozumianej wolnej woli, która ma najprawdopodobniej ewolucyjne podłoże i mogła powstać jako swoiste narzędzie przetrwania ${ }^{43}$. W takim ujęciu wolna wola jest

\footnotetext{
${ }^{38}$ R. F. Baumeister, Free will in scientific psychology, „Perspectives on Psychological Science”, styczeń 2008, t. 3, nr 1, s. 14-19.

${ }^{39}$ R. A. Thompson, Emotion Regulation: a Theme in Search of Definition, „Monographs for the Society for Research in Child Development", 1994, nr 59, s. 25-52.

${ }^{40}$ R. F. Baumeister, dz. cyt., s. 16.

${ }^{41}$ Tamże.

42 Tamże.

${ }^{43}$ Tamże, s. 14-19.
} 
przede wszystkim zdolnością odpowiadającą na konieczność dostosowania się do zaawansowanego życia społecznego, co obejmuje „wezwanie do przestrzegania abstrakcyjnych reguł i zasad kierujących działaniem, osobistą odpowiedzialność, świadomą refleksję, autonomiczną inicjatywę, zdolność do powstrzymywania się od pragnień mających ewolucyjne korzenie, ale które mogą być niekompatybilne z cywilizowanym życiem" ${ }^{44}$. Stąd jak wnioskuje Baumeister, być może wolna wola jako ewolucyjne narzędzie przetrwania, była konieczna nie do tego, aby być „wolnym”, lecz, nieco ironicznie, po to aby być zdolnym do podążania za regułami obecnymi w społeczeństwie (takimi jak prawo, reguły moralne, normy, zwyczaje, religijne zalecenia i zakazy, rozkazy $)^{45}$. Z jednej strony możemy się dostosowywać do zastanego ładu, co pozwala nam $\mathrm{w}$ nim prosperować, lub z drugiej strony możemy wymyślać własne reguły po to, aby później za nimi podążaćc ${ }^{46}$, ale jest to tylko reakcja na to, że musimy sami znaleźć taki system zachowań, który zapewni nam przetrwanie, czy realizację pewnych korzystnych dla nas zamierzeń, gdyż do tej pory nikt takiego właściwego nam systemu nie opracował. D r u g a różnica polega na postrzeganiu wolnej woli jako czegoś, co jest zasobem i jak każdy zasób jest ograniczone ${ }^{47}$. W tym przypadku chodzi o ograniczenia fizykalno-energetyczne. Nie można racjonalnie deliberować nad każdym elementem swojego życia, gdyż często nie ma na to czasu, musimy wiele decyzji podejmować szybko i automatycznie, a do tego nasz aparat poznawczy nie jest w stanie działać bez przerwy na najwyższych obrotach, potrzebuje odpoczynku i napływu zasobów energetycznych, szczególnie w sytuacjach stresowych i gdy musimy hamować swoje pragnienia, inaczej może to doprowadzić do podjęcia decyzji niezgodnej z przyjętymi przez nas regułami. To pociąga za sobą trzecią ró żnicę, jaką jest przyjęcie na wolną wolę perspektywy nie jako stałego atrybutu osoby, lecz czegoś, co zdarza nam się od czasu do czasu. Nie jesteśmy, lecz bywamy wolni, ponieważ świadoma kontrola zachowania jest biologicznie kosztowna ${ }^{48}$.

Nawet jeżeli uznamy, że wszystkie działania jednostek są jedynie „reakcjami" na rzeczywistość, która tym samym je determinuje, to odpowiedzi osób na wpływy środowiska są istotnym czynnikiem w sieci przyczynowej świata. Tak ujęty determinizm nie wyklucza autonomii. Takie działania jak

\footnotetext{
${ }^{44}$ Tamże, s. 16.

${ }^{45}$ Tamże.

46 Tamże, s. 17.

47 Tamże.

${ }^{48}$ Tamże, s. 14.
} 
podążanie za regułami, czy tworzenie własnych reguł, wskazują na aktywną rolę podmiotu, a jej badanie jest kluczowe dla zgłębiania istoty autonomii personalnej. Ponadto nawet zgadzając się z tezą, że „ja” jest zaledwie jednym z podprocesów realizowanych przez mózg, który otrzymuje informacje na temat podejmowanych działań niejako po ich wykonaniu, należy zwrócić uwagę na emergentne własności umysłu. W teorii neurobiologii interpersonalnej niesprowadzalny do sumy części, z których się składa, główny aspekt umysłu definiuje się jako „ucieleśniony i relacyjny proces regulacji przepływu informacji i energii" ${ }^{49}$. Ów proces regulacji wyraża się właśnie między innymi we wspomnianym angażowaniu się $\mathrm{w}$ reguły poprzez podążanie za nimi lub ich tworzenie i jest jednocześnie autonomiczną aktywnością umysłu.

Tym, czego moim zdaniem często brakuje w teoriach na temat autonomii, jest zagadnienie samowiedzy. Analizując już nawet samo znaczenie słowa autonomia, można zauważyć, że tym, co ją konstytuuje jest nie tylko samosterowność, ale także poznawanie samego siebie. Termin autonomia pocho-

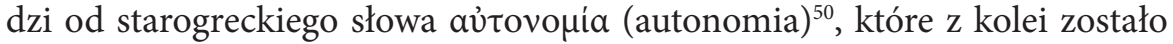

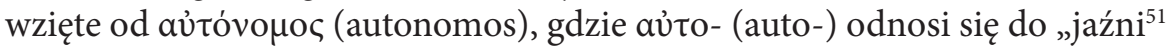
(samego siebie ${ }^{52}$ )" bądź do „czynności skierowanej ku wykonawcy lub rezultatu takiej czynności” ${ }^{3}$. Z kolei vó $\mu$ oৎ (nomos) oznacza "prawo" ${ }^{54}$ i stanowi „ostatni człon wyrazów złożonych będących nazwami nauk, dziedzin wiedzy lub systemów praw rządzących daną dziedziną" ${ }^{35}$. Zatem łącząc powyższe elementy, pod pojęciem autonomii będziemy rozumieli „kogoś, kto posiada oraz daje samemu sobie swoje własne prawo, własność samostanowienia o sobie lub kierowanie się własnymi prawami”"56 5758 , czyli autodeterminację,

${ }^{49}$ D. J. Siegel, The Developing Mind: How Relationships and the Brain Interact to Shape Who We Are, The Guilford Press, New York-London 2012, s. 2.

${ }^{50}$ B. Czupryn, Autonomia, [hasło w:] Powszechna encyklopedia filozofii, t. 9, Polskie Towarzystwo Tomasza z Akwinu, Lublin 2008,, s. 423.

${ }^{51}$ Tamże.

${ }^{52}$ Online Etymology Dictionary, http://www.etymonline.com/index.php?term=autonomy (dostęp: 12.05.2016).

${ }^{53}$ Słownik języka polskiego PWN, http://sjp.pwn.pl/szukaj/auto-.html (dostęp: 12.05.2016).

${ }^{54}$ Powszechna encyklopedia filozofii, Polskie Towarzystwo Tomasza z Akwinu, Lublin 2008 (dostęp: 12.05.2016).

${ }^{55}$ Stownik języka polskiego PWN.

${ }^{56}$ Powszechna encyklopedia filozofii.

${ }^{57}$ Online Etymology Dictionary.

${ }^{58}$ Oxford Dictionary, http://www.oxforddictionaries.com/definition/english/autonomy (dostęp: 12.05.2016). 
samostanowienie i samosterowność. Kierując się kompilacją kilku warstw znaczeń, można zauważyć, że autonomia będzie oznaczać aktywność samoświadomego podmiotu stosowną do poznania samego siebie: kładąc nacisk na rezultat zastosowania nakierowanej na samego siebie czynności poznawczej, poznania praw rządzących mną samym, „praw jaźni”, czyli właściwie mając na uwadze rezultat użycia pewnego zakresu samowiedzy, otrzymamy efekt poznania samego siebie w postaci samowiedzy oraz jej konsekwencji, na przykład jakiegoś działania, czy decyzji. Można zatem powiedzieć, że autonomia jest efektem poznania samego siebie i działania zgodnie z przekonaniami zawartymi w samowiedzy.

\section{Podsumowanie}

W artykule przedstawiłem problem autonomii w kognitywistyce, który można podzielić na problem autonomii podmiotowej i bezpodmiotowej, przy czym skupiłem się na analizie w aspekcie osobowym. Przygotowanie do badań nad autonomią wymaga zapoznania się z dotychczasowymi teoriami na jej temat w filozofii oraz psychologii, które pokazują, że na jej realizację składają się działanie zgodnie z samym sobą, spójnie z motywacją wewnętrzną i mogą się z nią wiązać takie zdolności poznawcze, jak responsywność na racje czy wyciąganie wniosków. Autonomia podmiotowa łączy się ściśle $\mathrm{z}$ atrybutem osoby posiadającej wolę - czyli z jej wolnością ${ }^{59}$, dlatego można ją utożsamiać $\mathrm{z}$ wolną wolą. Fenomenologia działania osób, która przekłada się na psychologiczne zjawisko samoregulacji jako zdolności do plastycznego kierowania swoim zachowaniem oraz życiem wewnętrznym, a także jako funkcjonowanie w obrębie motywacji wewnętrznej jest wyrazem wolnego działania.

Rozumienie autonomii jako złożenia samowiedzy i samoregulacji, w tym regulacyjnego i relacyjnego aspektu działania umysłu kierującego przepływem informacji i energii, w pełniejszy sposób wyraża to, jak należy podchodzić do problemu autonomii podmiotowej. Badanie aktywności podmiotu

\footnotetext{
${ }^{59}$ Por. dr Piotr Domeracki: „tylko woli można przypisywać wolność” - powołując się na Immanuela Kanta, Uniwersytet Mikołaja Kopernika, Wydział Humanistyczny, rozmowa prywatna, 10.12.2015.
} 
na styku kształtowania się samowiedzy i samoregulacji jest niezbędne dla rozwiązywania problemu autonomii podmiotowej w kognitywistyce.

\section{Bibliografia}

Baumeister R. F., Free Will in Scientific Psychology, „Perspectives on Psychological Science", styczeń 2008, t. 3, nr 1, s. 14-19.

Buss S., Personal Autonomy, [w:] The Stanford Encyclopedia of Philosophy (Winter 2014 Edition), Edward N. Zalta (ed.), http://plato.stanford.edu/archives/ win2014/entries/personal-autonomy/

Deci E. L., Vansteenkiste M., Self-Determination Theory and Basic Need Satisfaction: Understanding Human Development in Positive Psychology, „Ricerche di Psichologia" 2004, nr 27, s. 17-34.

Dryden J., Internet Encyclopedia of Philosophy. A Peer-Reviewed Academic Resource, http://www.iep.utm.edu/autonomy/

Duch W., Czy jesteśmy automatami? Mózgi, wolna wola i odpowiedzialność, [w:] Na ścieżkach neuronauki, red. P. Francuz, Wydawnictwo Naukowe KUL, Lublin 2010, s. 219-264.

Duch W., wykład „Wstęp do kognitywistyki”, Uniwersytet Mikołaja Kopernika, https://www.fizyka.umk.pl/ duch/Wyklady/Kog1/01-wstep.htm

Kadzikowska-Wrzosek R., Sita woli: autonomia, samoregulacja $i$ kontrola dziatania, Wydawnictwo Smak Słowa, Sopot 2013, s. 82-83.

Online Etymology Dictionary, http://www.etymonline.com/index.php?term=autonomy

Oxford Dictionary, http://www.oxforddictionaries.com/definition/english/autonomy

Powszechna encyklopedia filozofii, Polskie Towarzystwo Tomasza z Akwinu, t. 9, Lublin 2008.

Reber A. S., Słownik psychologii, red. I. Kurcz i K. Skarżyńska, Wydawnictwo Naukowe SCHOLAR, Warszawa 2002.

Ryan R. M., Deci E. L., Autonomy is no Illusion, [w:] Handbook of Experimental Existential Psychology, red. J. Greenberg, S. L. Koole, T. Pyszczynski, The Guilford Press, New York-London 2004, s. 449-479.

Ryan R. M., Deci E. L., Self-Regulation and the Problem of Human Autonomy: Does Psychology Need Choice, Self-Determination, and Will?, "Journal of Personality”, grudzień 2006, nr 74.6.

Siegel D. J., The Developing Mind: How Relationships and the Brain Interact to Shape Who We Are, The Guilford Press, New York-London 2012.

Stownik języka polskiego PWN, http://sjp.pwn.pl/szukaj/auto-.html 
Smith K., Neuroscience vs Philosophy: Taking Aim at Free Will, „Nature”, 2011, nr 477, s. 23-25.

Oficjalna witryna internetowa poświęcona Teorii Autodeterminacji, lista osób redagujących http://selfdeterminationtheory.org/faculty/, http://selfdeterminationtheory.org/theory/ (dostęp: 28.03.2016)

Thompson R. A., Emotion Regulation: a Theme in Search of Definition, „Monographs for the Society for Research in Child Development”, 1994, nr 59, s. 25-52.

Vohs K. D., Schooler J. W., The Value of Believing in Free Will, „Psychological Science”, styczeń 2008, nr 19(1), s. 49-54.

Żegleń U. M., Epistemologia a kognitywistyka, [w:] Przewodnik po epistemologii, red. R. Ziemińska, Wydawnictwo WAM, Kraków 2013, s. 457-493.

\section{Abstract \\ The Problem of Autonomy from the Cognitive Science Point of View}

The article presents the problem of autonomy in terms of cognitive science, dividing it into the problem of autonomy of the subject and problem of subjectless autonomy, and by outlining this division with relevant research questions. Overview of autonomy in a philosophical context, as personal autonomy, and as well as in the context of psychology, by using the theory of self-determination, has laid the foundations for the possibility of identifying the autonomy of the subject with the concept of free will. Focusing on the autonomy of the subject, by proposing more detailed definition of it was proposed: to understand it as a combination of selfknowledge and self-regulation. This could be the first step towards solving the problem of autonomy in terms of cognitive science.

Key words: autonomy, definition of autonomy, autonomy and free will, personal autonomy, theory of autodetermination, free will in psychology, self-knowledge, self-regulation 